\title{
Comprehensive Review on Metallurgical Upgradation Processes of Nickel Sulfide Ores
}

\author{
Kun Zhao ${ }^{1}$ (D) Feng Gao ${ }^{2}$ Q Qunying Yang ${ }^{1}$
}

Received: 19 June 2021 / Accepted: 4 January 2022 / Published online: 11 February 2022

(c) The Minerals, Metals \& Materials Society 2022

\begin{abstract}
With the vigorously growing demand of the steel industry, corrosion resistance alloys, clean energy industries, and a variety of engineered infrastructure or technology, high-grade nickel ores are being exhausted gradually in the world. This review outlines metallurgical processes for nickel production from various nickel sulfide ores resources, particularly focusing on recent developments in metallurgical processes to identify potential trends and technical requirements in nickel metallurgy. The main methods have been extensively reviewed for nickel extraction from nickel sulfide ores which maybe are potentially applicable to provide new ideas for smelting technology innovation of nickel and even other similar metals. The main metallurgical methods include pyrometallurgical and hydrometallurgy, containing smelting, leaching, and purification. The advantages and disadvantages of each typical process have been analyzed and compared in this review, and a special emphasis is put forth. Biological metallurgy is highly selective for recovery of nickel and the most promising method recommended for future research and development. Moreover, ion exchange offers useful method for extraction and purification of nickel. In addition, many of the typical new methods involved are also introduced in this article.
\end{abstract}

\section{Graphical Abstract}

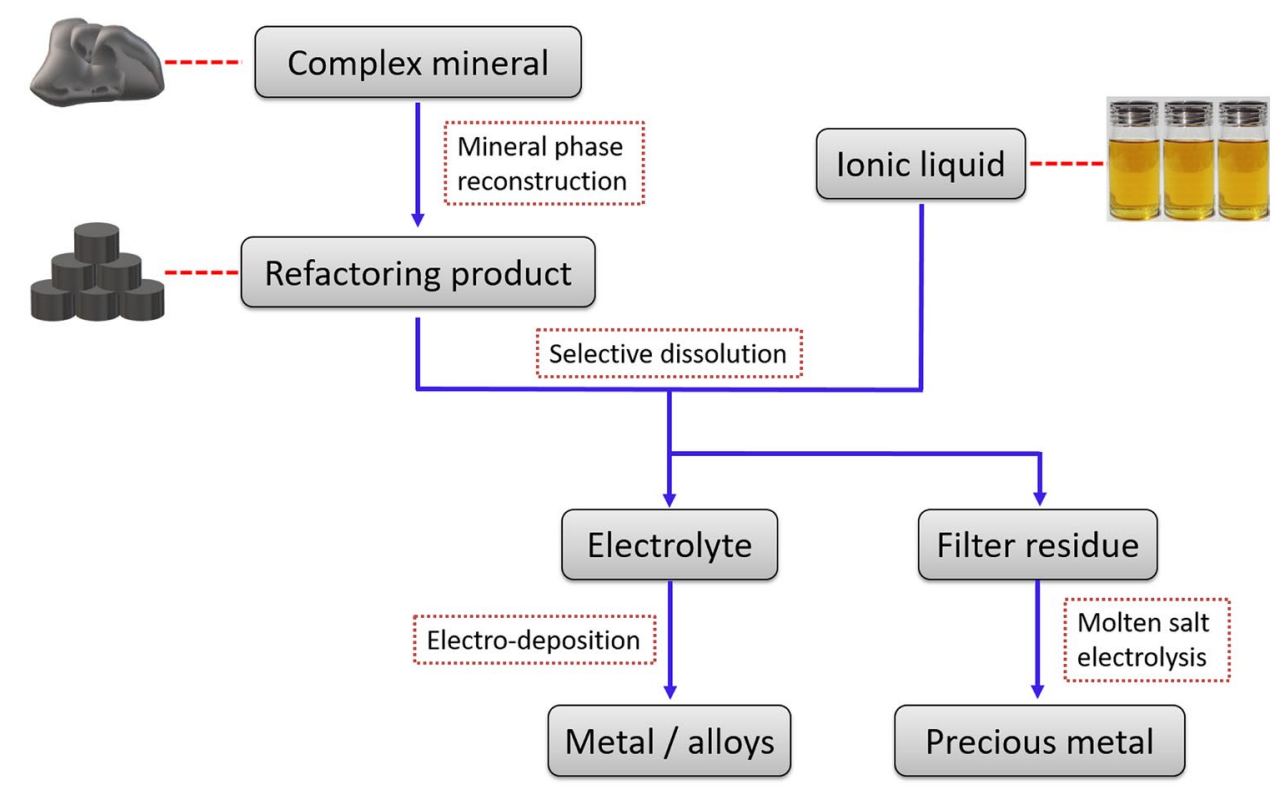

Keywords Nickel extraction $\cdot$ Nickel sulfide ores $\cdot$ Pyrometallurgical $\cdot$ Hydrometallurgy

The contributing editor for this article was Yongxiang Yang.

Extended author information available on the last page of the article 


\section{Introduction}

Nickel is one of the metals with extremely high strategic value in the development of national economy. Nickel has attracted continuous attentions owing to its superior performances such as good ductility, corrosion resistance, high-temperature resistance, and high strength, which have been considered as an essential basic material for high-temperature and high-strength alloys, heat-resistant materials, and stainless steel. Its application involves many fields such as metallurgy, machinery manufacturing, transportation, defense, and aerospace [1-3]. In addition, with the emergence of ecological and environmental problems, developing clean energy and achieving sustainable economic and social development have become the mainstream in current world. In terms of the emerging strategic industry of power batteries, ternary cathode materials containing nickel are replacing lithium iron phosphate as the key development direction of anode materials for power batteries because of their high capacity density [4-6]. Moreover, global photovoltaic, wind power, and other new energy sources and the need for large-scale energy storage in microgrids are increasing [7,8]. Nickel, as an indispensable key material in the fields mentioned above, is expected to have explosive growth in demand, which will make the development of the nickel industry more imaginative. In order to gain an edge in emerging industries, the research and development of new technologies for further low-cost and efficient production of nickel have become one of the most concerned research hotspots in the field of nickel technology.

Keeping in view of the widespread data on resources of nickel and status of different technologies for nickel extraction, this article presents a brief overview about nickel sulfide ore characteristics and summarizes the different types of upgradation metallurgical processing used to enhance diverse kinds of nickel sulfide ores found in different parts of world. An overview about the future trends of nickel industry observed in the field of metallurgy techniques has also been discussed along with the challenges and gap areas associated with conventional ore processing methods.

\section{Characteristics of Nickel Sulfide Ore Resources}

The world reserves of nickel are estimated at 94 million tons of nickel metal content, which is rich in resources [9]. The regional distribution of global nickel reserves is relatively concentrated. The top three countries, Indonesia, Australia, and Brazil, all account for more than $10 \%$, which together account for about $60 \%$ of the global nickel reserves. The land-based resources available for the preparation of nickel mainly include nickel sulfide ore and nickel oxide ore, and the sulfide-oxide ratio in current nickel reserves is believed to be about 4:6.

Sulfide ores originated from hydrothermal processes related to volcanic areas. Nickel, copper, cobalt, iron, and other precious metals such as gold or platinum group metals contained in magma crystallized and precipitated in the form of sulfide, which eventually evolved into a nickel sulfide deposit $[10,11,13]$. The forms and distribution of main nickel-bearing minerals in nickel sulfide deposits are shown in Table 1. In addition to the mentioned, other associated nickel-free minerals such as chalcopyrite $\left(\mathrm{CuFeS}_{2}\right)$, pyrrhotite $\left(\mathrm{Fe}_{7} \mathrm{~S}_{8}\right)$, chromite $\left[(\mathrm{Mg}, \mathrm{Fe}) \cdot \mathrm{Cr}_{2} \mathrm{O}_{4}\right]$, and gangue compositions (ferric oxide, silicon dioxide, magnesium oxide, calcium oxide, and aluminum oxide, etc.) also are contained in nickel sulfide deposits [14-16]. For some low-grade nickel sulfide ore from

Table 1 The forms and distribution of main nickel-bearing minerals in nickel sulfide deposits [10-12]

\begin{tabular}{|c|c|c|c|}
\hline Mineral name & Chemical formula & Location & $\mathrm{Ni}$ content (wt\%) \\
\hline Heazlewoodite & $\mathrm{Ni}_{3} \mathrm{~S}_{2}$ & USA, Australia & $\sim 73$ \\
\hline Millerite & $\mathrm{NiS}$ & Australia, Canada, USA & $64-65$ \\
\hline Polydymite & $\mathrm{Ni}_{3} \mathrm{~S}_{4}$ & Germany & $\sim 58$ \\
\hline Maucherite & $\mathrm{Ni}_{11} \mathrm{As}_{8}$ & Germany & $\sim 52$ \\
\hline Niccolite/Nickeline & NiAs & Switzerland, Germany, Canada, Australia & $\sim 44$ \\
\hline Violarite & $\mathrm{Ni}_{2} \mathrm{FeS}_{4}$ & Canada & $\sim 39$ \\
\hline Gersdorffite & NiAsS & Australia, Morocco & $\sim 35$ \\
\hline Pentlandite & $(\mathrm{Ni}, \mathrm{Fe})_{9} \mathrm{~S}_{8}$ & Russia, South Africa, Canada, Australia, Norway & $\sim 34$ \\
\hline Breithauptite & $\mathrm{NiSb}$ & Canada, Norway, Australia, Italy, India & $32-33$ \\
\hline Annabergite & $\mathrm{Ni}_{3}\left(\mathrm{H}_{2} \mathrm{O}\right)_{8}\left[\mathrm{AsO}_{4}\right]_{2}$ & Germany & $29-30$ \\
\hline Siegenite & $(\mathrm{Co}, \mathrm{Ni})_{3} \mathrm{~S}_{4}$ & Germany, Czech Republic, USA, Zaire & $28-29$ \\
\hline Rammelsbergite & $\mathrm{NiAs}_{2}$ & Canada, Germany & $\sim 28$ \\
\hline
\end{tabular}


lean ore regions, for example, a sulfide mine in Shaanxi, China, due to the grade of nickel sulfide raw ore generally between 0.3 and $3.0 \%$, it is necessary to enrich the ore by mineral processing before smelting. Sulfide ores are crushed and ground in order to liberate nickel minerals by selective flotation, in place of, or in conjunction with magnetic separators. After that, nickel concentrate (containing 6-20\% Ni) can be collected. The enriched concentrate contains fuel composition in the form of iron sulfide, which can reduce the energy consumption of smelting and facilitate the comprehensive utilization of resources. Coupled with the mature smelting technologies, nickel sulfide ore is currently the most important source of mineral production in the nickel industry, which contributes approximately $70 \%$ of nickel production [17].

However, with the long-term mining of nickel sulfide ore and none major breakthroughs in the exploration of new resources, its reserves are declining gradually. Relatedly, the difficulty of traditional mines mining, beneficiation, and smelting also increases. Therefore, it is of great significance to further develop low energy consumption and sustainable technologies to extract nickel from different types of nickel sulfide ores.

\section{Main Metallurgical Process}

Extracting nickel from sulfide ore generally refers to the process of melting nickel from nickel sulfide ore into low-nickel matte or leaching nickel into solution. Its metallurgical technologies are primarily concerned with pyrometallurgy and hydrometallurgy. The overall process flowchart of nickel extraction from nickel sulfide ores is shown in Fig. 1.

\section{Pyrometallurgy}

Extracting nickel from nickel sulfide ore by the pyrometallurgical as the main production process of nickel at present, its core step is matte smelting. The major chemical reactions of the matte-producing process could be described as follows [18]:

$2 \mathrm{FeS}+3 \mathrm{O}_{2}=2 \mathrm{FeO}+2 \mathrm{SO}_{2}$

Slagging reaction : $2 \mathrm{FeO}+\mathrm{SiO}_{2}=2 \mathrm{FeO} \cdot \mathrm{SiO}_{2}$

Matte producing $: x \mathrm{FeS}+y \mathrm{MS}=[x \mathrm{FeS} \cdot y \mathrm{MS}]$

The matte (eutectic melts) with low melting point formed by different metal sulfide (MS) and ferrous sulfide can be interfused completely in liquid state. However, the matte is mutual incoherence with slag because of different densities. Therefore, different MS can be effectively enriched in the matte during the melting process, while the impurity oxides can be separated by combining with silicon dioxide to form slag. The low-grade nickel matte obtained by the matte smelting process should be further enriched by converter blowing. Blowing air into the furnace and adding quartz as a flux, iron, ferrous sulfide, and other impurities in the lowgrade nickel matte make slag with quartz after oxidized. As a result, the high-grade nickel matte with a higher content of the valuable metal (such as nickel, cobalt and copper, etc.) and slag with low valuable metal levels can be collected. Meanwhile, part of the matte and other volatile impurities maybe discharged with flue gas after oxidized, resulting in partial loss.

Currently, the main smelting processes of nickel sulfide ore involve flash smelting and pool smelting [19-22]. Spraying the deeply dehydrated powder concentrate from the top

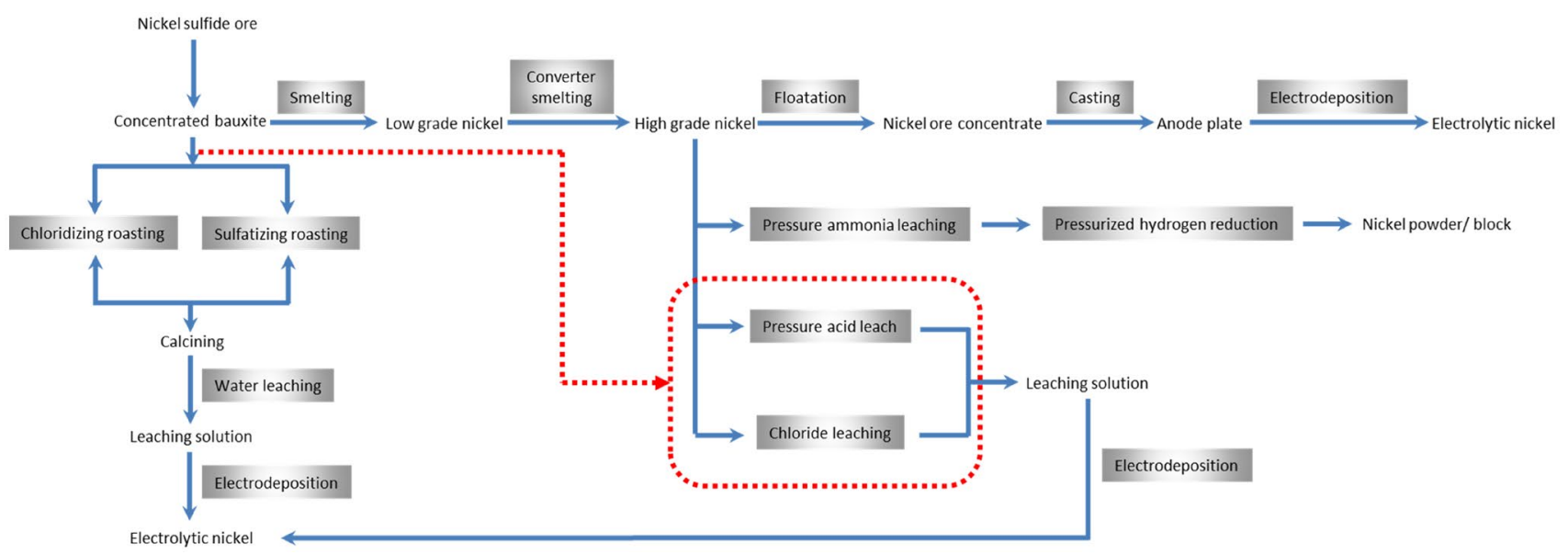

Fig. 1 Overall flowchart for nickel extraction from nickel sulfide ores 
into the reactor at $1450-1550^{\circ} \mathrm{C}$ during flash smelting. The advantage of flash smelting is that the decomposition, oxidation, and melting of sulfide can be accomplished quickly, generally in 2-3 s. The time efficiency and reaction completion of matting process are improved synchronously. In contrast, matte producing as an intermediate process is undergone in bath smelting. The mixture of sulfide concentrate, calcine of partial oxidation, nickel-bearing revert, and fluxes is smelted at $1200-1300{ }^{\circ} \mathrm{C}$. Finally, metal sulfides (nickel matte) and oxide (slag) can be generated after a series of chemical reactions, melting and dissolving process. The low-grade nickel matte produced by flash smelting and bath smelting needs further converting to produce the high-grade nickel matte to meet the treatment requirements of refining process. The typical production process of high-grade nickel matte is shown in Fig. 2. Then, after grinded, copper and nickel contained in the high-grade nickel matte can be separated preliminarily by flotation, and the concentrate of copper and nickel can be obtained, respectively. The nickel concentrate is smelted and blown to prepare nickel sulfide electrode, and electrodeposition nickel can be produced by electrorefining finally.

However, the results indicated that the nickel content in slag is high in the above both smelting methods. Therefore, it is necessary to dilute the slag before recovering, which undoubtedly increases the cost of treatment. To sum up, although realizing large capacity and high efficiency, there are still some defects existing in the extracting nickel process from sulfide ore by the pyrometallurgical, such as high energy consumption, serious nickel loss, high emission intensity of smelting process waste gas, and high risk of secondary pollution to the environment. Simultaneously, with the increasing mining intensity of nickel sulfide ore in the world, mineral grade is decreasing year by year. However, the traditional pyrometallurgical matte smelting has higher requirements on the grade of nickel concentrate, so it is no longer suitable for the treatment of complex nickel sulfide ore containing multimetals.

Wang et al. $[23,24]$ proposed a one-step extraction process of nickel from nickel sulfide concentrates by iron addition. The mixture of concentrate and iron after roasted at $800{ }^{\circ} \mathrm{C}$ for $240 \mathrm{~min}, \sim 96.8 \%$ of nickel could be extracted in the form of ferronickel alloy. In this solid-state nickel extraction process, it can be achieved that recovered nickel values into alloy and simultaneously retained the bulk of sulfur of the nickel sulfide concentrate in the solid iron sulfide, thus mitigating the potential sulfur dioxide emissions.

\section{Hydrometallurgy}

Hydrometallurgical process for nickel sulfide ore was developed in 1970s, which is to transfer valuable metals to liquid phase from solid ore by chemical leaching, and then extracts valuable metals by solvent extraction, chemical

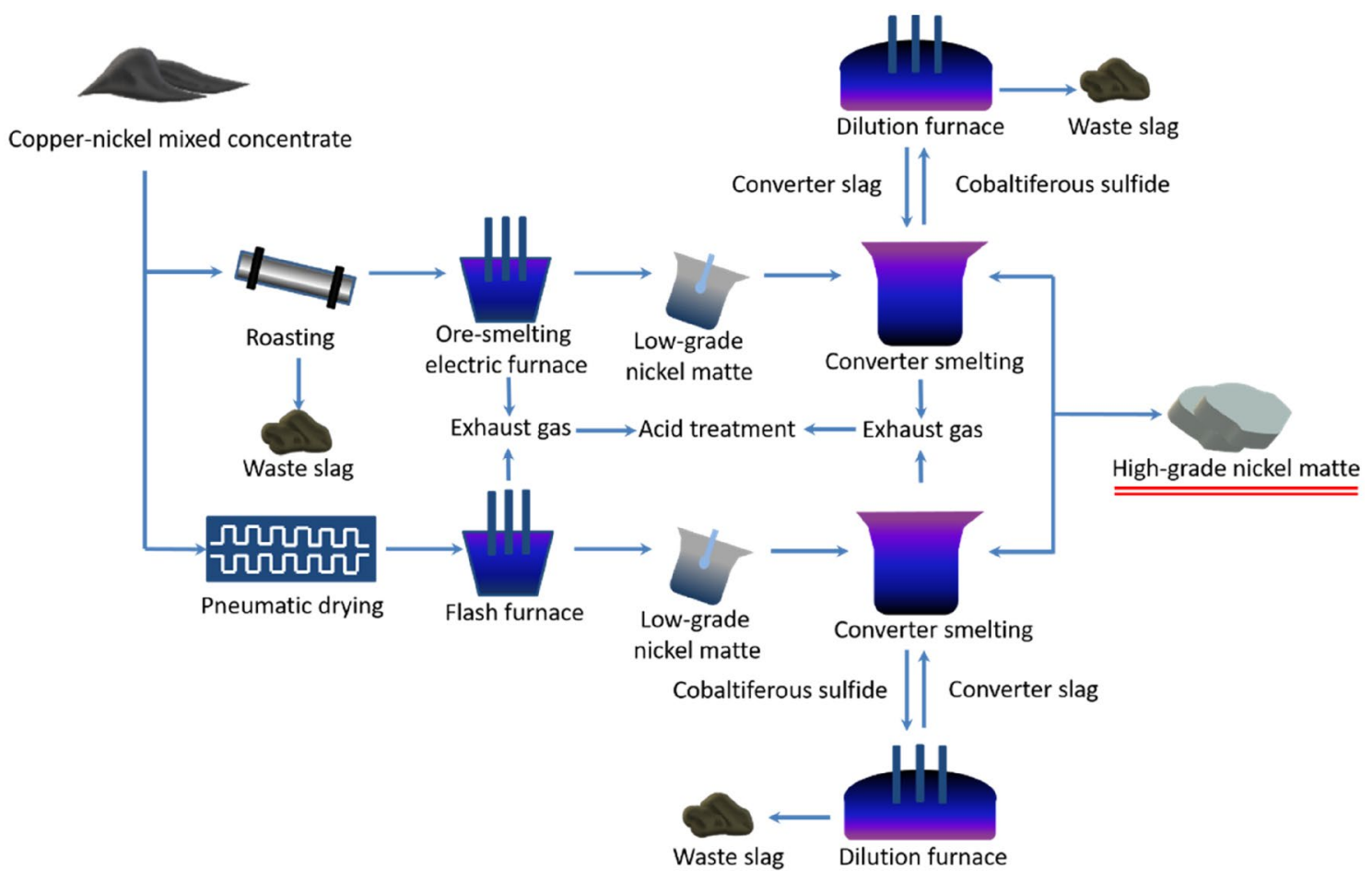

Fig. 2 The typical flowchart of high-grade nickel matte production 
precipitation, crystallization, and other means [25-27]. Generally during a hydrometallurgical process of nickel sulfide ore, high-grade nickel matte or nickel concentrate is used as raw material.

\section{Pressure Leaching}

Considering that the most phases of nickel sulfide ore have stable crystal structure, in order to further strengthen the mass transfer process between leaching agent and mineralogical phase, pressure leaching is usually used to improve the extraction rate of nickel. According to the different leaching agents, there are two ways of pressure leaching: pressure ammonia leaching and pressure acid leaching.

Pressure Ammonia Leaching Under a certain E-pH condition, nickel and cobalt in mineralogical phase can enter into the solution by forming ammine complexes in ammoniaammonium solution while other impurity metals remained in the residue, so as to realize the selective leaching of nickel and cobalt from nickel sulfide concentrate [28-30]. The complexation reactions during this process are as follows [31]:

$$
\begin{aligned}
& \mathrm{NiS}+2 \mathrm{O}_{2}+6 \mathrm{NH}_{3}=\mathrm{Ni}\left(\mathrm{NH}_{3}\right)_{6} \cdot \mathrm{SO}_{4} \\
& 4 \mathrm{CoS}+9 \mathrm{O}_{2}+20 \mathrm{NH}_{3}+2\left(\mathrm{NH}_{4}\right)_{2} \mathrm{SO}_{4} \\
& =2\left[\mathrm{Co}\left(\mathrm{NH}_{3}\right)_{6}\right]_{2}\left(\mathrm{SO}_{4}\right)_{3}+2 \mathrm{H}_{2} \mathrm{O}
\end{aligned}
$$

Aqueous ammonia and air are used as oxidants, and twostage leaching is carried out at $\sim 80{ }^{\circ} \mathrm{C}$ and $\sim 900 \mathrm{kPa}$. After that, the leaching residue is washed by counter current filter. The leach solution is boiled to recover the ammonia, while the thiosulphates and thiosulfonates are dismutated for precipitating to copper of high purity $[32,33]$. The flow of pressure ammonia leaching is shown in Fig. 3.

The recovery rate of nickel, cobalt, and copper can reach $90 \%, 50 \%$, and $88 \%$, respectively, through ammonia leaching process. It can be realized that the resource utilization

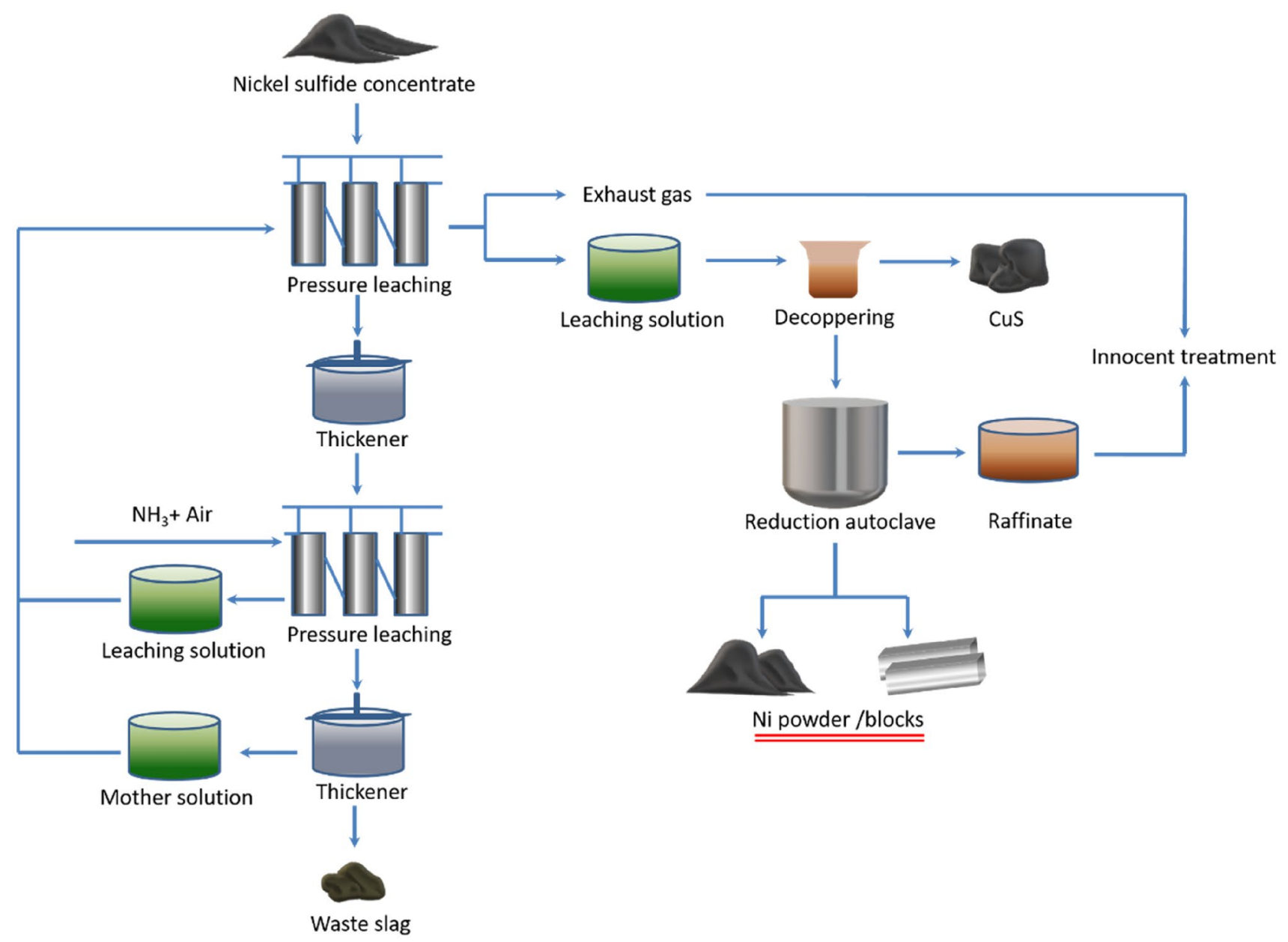

Fig. 3 Typical flowchart of pressure ammonia leaching process 
of sulfur in nickel sulfide concentrate by pressure ammonia leaching. Meanwhile, it indicates that ammonia leaching process is suitable for the treatment of refractory polymetallic ore. However, high equipment requirements and low efficiency of precious metal extraction limit the application of ammonia leaching process in industrial production, which also causes it has been gradually replaced.

Pressure Acid Leaching (PAL) In consideration of the special mineralogical characteristics of nickel sulfide ore, oxygen is regarded as a common oxidant in nickel extraction from nickel sulfide ores. According to Henry's law, the extraction velocity can be significantly increased with the increasing of oxygen partial pressure. Thus, oxygen pressure acid leaching has getting more and more attention in recent years.

Oxygen and acid are used as oxidant and leaching agent, respectively, valuable metals can be extracted from nickel sulfide concentrate into the solutions by pressure acid leaching, which is used as a prominent hydrometallurgical process industrially for the production of nickel. By controlling the leaching conditions, it can be realized that the leaching rate of nickel and cobalt is higher than $85 \%$, while the leaching of copper and other heavy metals is inhibited [25, 34]. The main reactions during the pressure acid leaching process are shown as following [31, 34]:

$2 \mathrm{Ni}+\mathrm{O}_{2}+2 \mathrm{H}_{2} \mathrm{SO}_{4}=2 \mathrm{NiSO}_{4}+2 \mathrm{H}_{2} \mathrm{O}$

$2 \mathrm{Cu}+\mathrm{O}_{2}+2 \mathrm{H}_{2} \mathrm{SO}_{4}=2 \mathrm{CuSO}_{4}+2 \mathrm{H}_{2} \mathrm{O}$

Nickel sulfide leaching reactions are as follows:

$2 \mathrm{Ni}_{3} \mathrm{~S}_{2}+\mathrm{O}_{2}+2 \mathrm{H}_{2} \mathrm{SO}_{4}=2 \mathrm{NiSO}_{4}+4 \mathrm{NiS}+2 \mathrm{H}_{2} \mathrm{O}$

$8 \mathrm{NiS}+\mathrm{O}_{2}+2 \mathrm{H}_{2} \mathrm{SO}_{4}=2 \mathrm{Ni}_{3} \mathrm{~S}_{4}+2 \mathrm{NiSO}_{4}+2 \mathrm{H}_{2} \mathrm{O}$

Under a hypoxia condition, copper in the solution can enter into the slag as follows:

$\mathrm{NiS}+\mathrm{CuSO}_{4}=\mathrm{CuS}+\mathrm{NiSO}_{4}$

$4 \mathrm{Ni}_{3} \mathrm{~S}_{4}+9 \mathrm{CuSO}_{4}+8 \mathrm{H}_{2} \mathrm{O}=\mathrm{Cu}_{9} \mathrm{~S}_{5}+9 \mathrm{NiS}+3 \mathrm{NiSO}_{4}+8 \mathrm{H}_{2} \mathrm{SO}_{4}$

$\mathrm{Ni}_{3} \mathrm{~S}_{2}+2 \mathrm{CuSO}_{4}=\mathrm{NiSO}_{4}+\mathrm{NiS}+\mathrm{Cu}_{2} \mathrm{~S}$

The PAL process was applied for the first time in industry at Outokumpu Harjavalta Refineny [35]. Valuable metals were leached from the high-grade nickel matte by threestage of atmospheric pressure leaching and one-stage of pressure leaching. The leaching rates of nickel and cobalt were up to $98 \%$ and $97 \%$, respectively. Based on this, the process had been improved by Fukang Smelting Plant in Xinjiang of China. The technical route of one-stage atmospheric pressure leaching combine with one-stage pressure leaching was carried out successfully for solving the problem of difficult separation of nickel and cobalt during the leaching process of high-grade nickel matte. Furthermore, significant shortening of the process flow was achieved in the new route though eliminating the electrolytic deposition process for copper removal [36]. In addition, according to the different properties of raw materials, a typical sulfuric acid leaching process adopting two stages of high pressure leaching of copper and nickel matte was proposed by Sherritt Gordon Mines of Canada, and its process flow is shown in Fig. 4.

The total recoveries of nickel, cobalt, copper, and sulfur were more than $99.9 \%$ after the two-stage pressure acid leaching. The mechanisms of leaching are as follows [27, 37]:

$$
\begin{aligned}
& (\mathrm{Fe}, \mathrm{Ni})_{9} \mathrm{~S}_{8}+45 \mathrm{O}_{2}+36 \mathrm{H}_{2} \mathrm{SO}_{4} \\
& \quad=36 \mathrm{NiSO}_{4}+18 \mathrm{Fe}_{2} \mathrm{O}_{3}+36 \mathrm{H}_{2} \mathrm{O}+64 \mathrm{~S}^{0} \\
& 2 \mathrm{Fe}_{1-x} \mathrm{~S}+(1-x) \mathrm{O}_{2}+2(1-x) \mathrm{H}_{2} \mathrm{SO}_{4} \\
& \quad=2(1-x) \mathrm{FeSO}_{4}+2 \mathrm{SO}+2(1-x) \mathrm{H}_{2} \mathrm{O} \\
& \mathrm{Mg}_{3} \mathrm{Si}_{4} \mathrm{O}_{10}(\mathrm{OH})_{2}+3 \mathrm{H}_{2} \mathrm{SO}_{4}=3 \mathrm{MgSO}_{4}+4 \mathrm{SiO}_{2}+4 \mathrm{H}_{2} \mathrm{O}
\end{aligned}
$$

$\mathrm{FeCuS}_{2}+2 \mathrm{H}_{2} \mathrm{SO}_{4}+\mathrm{O}_{2}=\mathrm{FeSO}_{4}+4 \mathrm{CuSO}_{4}+2 \mathrm{~S}^{0}+2 \mathrm{H}_{2} \mathrm{O}$

Part of the sulfur can be converted into sulfuric acid for sustaining to react with minerals, which is favorable for reducing the total acid consumption and improving the purity of the product effectively [27]. However, coating layer formed by another part of sulfur potentially covers valuable metals resulting in a decrease in metal leaching rate. The disadvantage of this process is that it has poor adaptability to raw materials and is only suitable for leaching high-grade ores. Furthermore, this process also possesses some defects as high requirements on equipment and poor continuous production capacity.

McDonald et al. [25] treated a high iron-low nickel concentrate by pressure oxidation at $250{ }^{\circ} \mathrm{C}$, and the extraction of base metals from such nickel sulfide concentrates is rapid. The controlled oxidation of feed sulfide minerals demonstrated that the hydrothermal oxidation of pentlandite occurs via violarite and subsequently vaesite. Under the conditions employed, the oxidation of pyrrhotite generates both pyrite and marcasite as intermediates while chalcopyrite was noted to oxidize via a covellite intermediate. Furthermore, the oxidation of nickel sulfides, iron sulfides, and copper sulfides occurs at different rates. Muszer et al. [38] defined the behavior of complex copper mineral phases by studying the pressure leaching process of copper sulfide concentrate. Provis et al. [39] presented a semi-empirical 


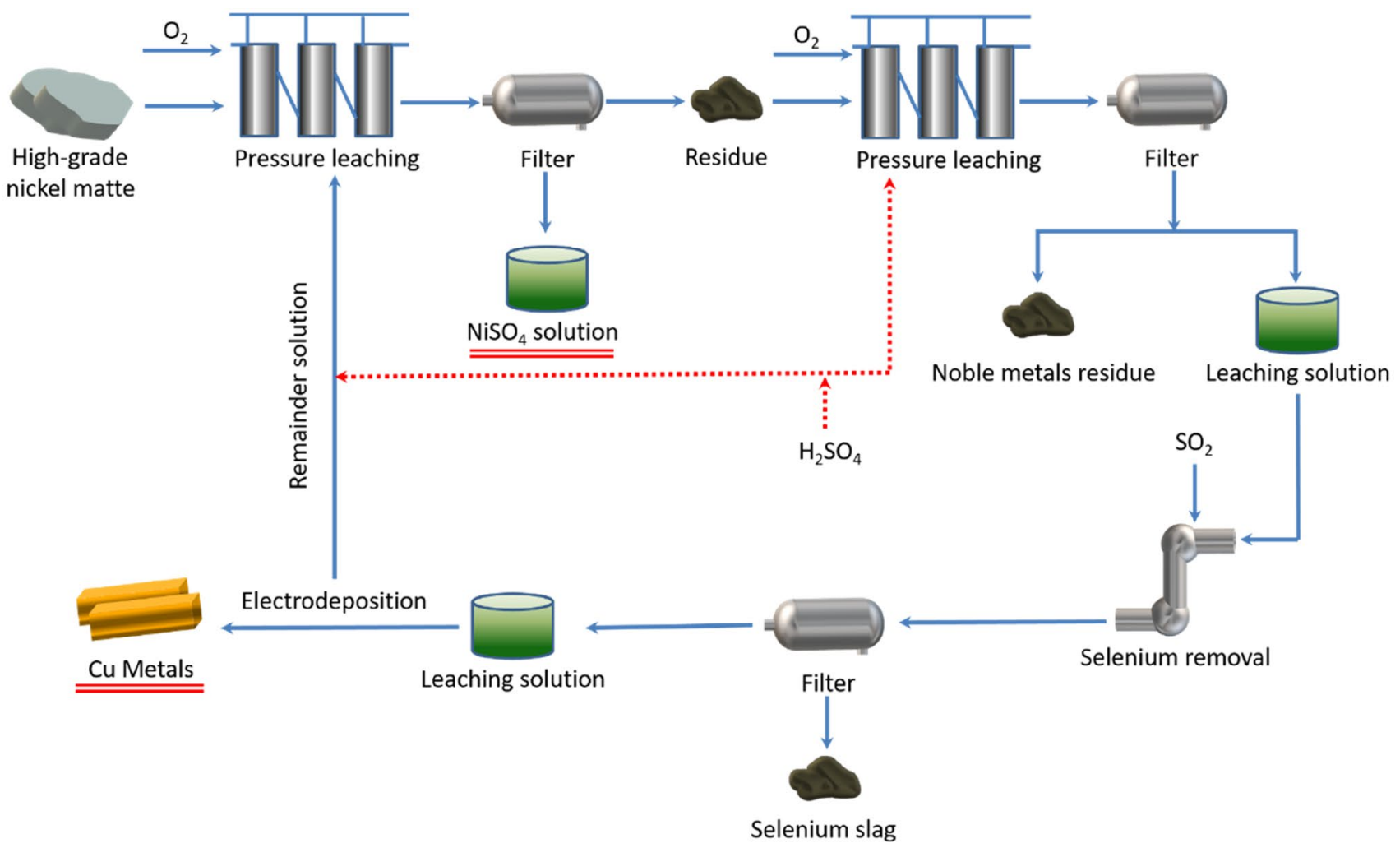

Fig. 4 Schematic diagram of two-stage pressure acid leaching

mathematical model for the acid-oxygen pressure leaching of nickel-copper matte; the primary controlling factor in the leaching process is found to be galvanic inhibition of the more highly oxidized copper and nickel sulfide species by less oxidized species, particularly nickel alloy and nickel subsulfide. Huang et al. [27] investigated the recovery of copper, nickel, and cobalt from the acidic pressure leaching solutions of a low-grade sulfide flotation concentrates. The technique proposed by Huang et al. [27] included four main steps: acidic pressure leaching — solvent extraction separation of copper-high-temperature hydrolysis precipitation removing of iron- selectively precipitated of nickel and cobalt using sodium sulfide. It was reported that the total percent recovery of copper could reach $95 \%$ or more and that of nickel and cobalt was all more than $99 \%$. In the processing, the percent removal of impurities, such as iron, magnesium, and calcium, was all also near to $99 \%$.

\section{Atmospheric Leaching}

Atmospheric Acid Leaching (AL) Atmospheric acid leaching is considered as a potential technological route because it is conducted at a low temperature and requires open vessels avoiding the need of expensive autoclaves and has the advantages of simple process, low energy consumption, and simple operation. AL process generally uses nickel sulfide concentrate as raw material, the main phases of which are nickel subsulfide, cuprous sulfide, and nickel-cobalt alloy $[40,41]$. In the presence of sulfuric acid and oxygen, the solubility of metallic nickel, nickel subsulfide, and cuprous sulfide is different, as completely dissolved, partially dissolved, and undissolved, respectively. The following reactions take place during the leaching [42]:

$$
\begin{aligned}
& 3 \mathrm{MS}+8 \mathrm{HNO}_{3}=2 \mathrm{NO}+3 \mathrm{M}\left(\mathrm{NO}_{3}\right)_{2}+3 \mathrm{~S}^{0}+4 \mathrm{H}_{2} \mathrm{O} \\
& \mathrm{FeS}+4 \mathrm{HNO}_{3}=\mathrm{Fe}\left(\mathrm{NO}_{3}\right)_{3}+\mathrm{NO}+\mathrm{S}^{0}+2 \mathrm{H}_{2} \mathrm{O} \\
& \mathrm{M}\left(\mathrm{NO}_{3}\right)_{2}+\mathrm{H}_{2} \mathrm{SO}_{4}=\mathrm{MSO}_{4}+2 \mathrm{HNO}_{3} \\
& \mathrm{~S}^{0}+2 \mathrm{HNO}_{3}=\mathrm{H}_{2} \mathrm{SO}_{4}+2 \mathrm{NO} \\
& 2 \mathrm{NO}+\mathrm{O}_{2}+\mathrm{H}_{2} \mathrm{O}=\mathrm{HNO}_{3}+\mathrm{HNO}_{2}
\end{aligned}
$$

$\mathrm{AL}$ process has the advantages of simple process, low energy consumption, less equipment investment, and easy control of operating conditions [43, 44], but its 
disadvantages, such as low leaching rate, difficult separation of leaching solution, high nickel content in leaching residue and large amount of waste water, also increase in cost of production.

Water Leaching A pyrometallurgical pretreatment followed by hydrometallurgical processing plays an important role in the treatment of nickel sulfide ore. Water leaching is a typical combination process of hydro- and pyrometallurgy.

\section{- Chloridizing Roasting-Water Leaching}

In recent years, due to its good adaptability to feedstock and pollution-free treatment of sulfur, chloridizing roasting-water leaching as an alternative low-energy technology has attracted wide attention in the processing of sulfide minerals [45, 46]. Generally, chlorine-containing reagents characterized with variety and low price of origin materials, such as chlorine, hydrogen chloride, calcium chloride, sodium chloride, magnesium chloride, and aluminum chloride, are widely used as chlorinating agents in the process of roasting. Raw mineral materials are mixed with chlorinating agents and roasted at $300 \sim 450{ }^{\circ} \mathrm{C}$. After that, nickel and cobalt in the roasted product are existed in the form of soluble chlorides, which easily dissolve into the solution during water leaching. Because of high reactivity and leaching efficiency, chlorination roasting-water leaching possesses unique advantages for the treatment of low-grade nickel sulfide ore.

Kershner et al. [47] roasted nickel sulfide ore with sodium chloride at $450{ }^{\circ} \mathrm{C}$ for $2 \mathrm{~h}$ and then leached the roasted product with dilute hydrogen chloride. When the $\mathrm{pH}$ value was 1 , the leaching rates of nickel and cobalt reached $\sim 90 \%$ and $\sim 95 \%$, respectively. Mukherjee et al. [48] used sodium chloride as chlorinating agent for the chloridizing roast of sulfide concentrate. The results showed that the extraction rates of nickel and copper were all up to $99 \%$ by water leaching after roasted at $350{ }^{\circ} \mathrm{C}$ for $4 \mathrm{~h}$. V. A. Imideev et al. [49] optimized the roasting process of nickel sulfide concentrate with sodium chloride. The product obtained after being roasted with the mass ratio of sodium chloride to concentrate was $1: 2$ at $400{ }^{\circ} \mathrm{C}$ for $1.5 \mathrm{~h}$, was carried out by water leaching, the leaching rates of nickel, copper and cobalt could reach $84.3 \%, 87.7 \%$ and $92.9 \%$, respectively. Li et al. [50] proposed a novel temperature-programmed ammonium chloride roasting-water leaching process to extract nickel from polymetallic sulfide minerals. The results indicated that sulfide chlorination occurred because of ammonium chloride and the formed intermediates, including metal chlorides and chlorine, and the final extraction rate of nickel can reach $\sim 97 \%$. Cui et al. [51] reported a new selective chlorination roasting and water leaching process to treat complex nickel sulfide ore using anhydrous aluminum chloride as the solid chlorination agent. The chlorination mechanism analysis showed that the predominant matters contributing to the chlorination of talc, lizardite, and magnetite were aluminum chloride (both solid or gas) and the generated hydrogen chloride: however, the chlorination of metal sulfide (pentlandite, chalcopyrite, and pyrite) was mostly contributed by the generated chlorine. However, chlorination has strong corrosiveness to equipment, which reduces the economic benefits of this process.

\section{- Sulfating Roasting-Water Leaching}

The sulfating roasting process of nickel sulfide ore is essentially a process of selective oxidation of metals in minerals. In this process, air or oxygen-enriched air is generally used as oxidant, and a multiphase reaction takes place between solid phase and gas phase. After roasting, valuable metals such as nickel, cobalt, and copper are converted into sulfate, while iron is converted into ferrous oxide, so as to realize the separation of nickel and iron by water leaching. The involved main reactions of valuable metals taking place in roasting are as follows [52]:

$2 \mathrm{MS}+3 \mathrm{O}_{2}=2 \mathrm{MO}+2 \mathrm{SO}_{2}$

$2 \mathrm{SO}_{2}+\mathrm{O}_{2}=2 \mathrm{SO}_{3}$

$\mathrm{MO}+\mathrm{SO}_{3}=\mathrm{MSO}_{4}$

The saturated vapor pressure of ferric sulfate at roasting temperature (generally at $500-700{ }^{\circ} \mathrm{C}$ ) is much higher than that of the sulfate of valuable metals (nickel, copper, and cobalt). Thus, iron mainly exists in the form of ferric oxide in the calcine. Theoretically, the effective separation of cobalt, nickel, copper, and iron can be achieved by water leaching. However, the gas phase reaction rate of Eqs. (23) is slow in the actual mineral reaction system, and the surface of mineral particles is easy to be coated by products during the sulfation as shown in Eqs. (24), resulting in the low extraction rates of cobalt, nickel, and copper. In order to optimize the process of sulfating roasting, Thornhill et al. [53] used sodium sulfate as roasting agent to improve the leaching rate of nickel. The reason is that sodium sulfate can destroy the stable structure of nickel ferrite $\left(\mathrm{NiFe}_{2} \mathrm{O}_{4}\right)$ and make it transform into nickel sulfate. Yu et al. [54] also discussed the influence mechanism of sodium sulfate on the sulfating roasting of nickel sulfide concentrate. The sulfating reaction interface can be moistened by composite sulfate melt, leading to an increase in activation sites of the interface. Meanwhile, the melt coated by the reaction interface acts as the medium for sulfur trioxide diffusion into the inner unreacted sulfide core, which realizes the efficient transportation of sulfur trioxide through the chemical balance between sulfate ion and thiosulfate ion and further promotes 
the sulfate formation of nickel. Mu et al. [55] reported a process for synchronous extraction of nickel and copper from a mixed oxide-sulfide nickel ore in a low-temperature roasting system. In this process, sodium sulfate was used as an additive for improving the extraction of nickel by converting into Na-pyrosulfate, and more than $97 \%$ of nickel could be extracted after roasting at $450{ }^{\circ} \mathrm{C}$ for $4 \mathrm{~h}$. Liu et al. [56] used ammonium sulfate roasting-water leaching process to treat low-grade nickel sulfide ore. Firstly, ammonium sulfate and nickel sulfide ore were mixed according to the mass ratio of 4:5, and then roasted at $400{ }^{\circ} \mathrm{C}$ for $2 \mathrm{~h}$ for water leaching. The leaching rates of nickel, copper, iron, and magnesium were $83.48 \%, 76.24 \%, 56.43 \%$, and $62.15 \%$, respectively. Cui et al. [57] reported a two-stage roasting-water leaching process for extracting valuable metals from copper-nickel sulfide concentrate. In the first stage, ammonium sulfate was added and roasting was carried out at $500{ }^{\circ} \mathrm{C}$ for $2 \mathrm{~h}$; in the second stage, sodium sulfate was added for roasting at $680{ }^{\circ} \mathrm{C}$ for $2 \mathrm{~h}$; finally, the leaching rates of nickel, copper, and cobalt were $92.1 \%, 97.6 \%$, and $99.3 \%$ by leaching for $2 \mathrm{~h}$ in water at $95^{\circ} \mathrm{C}$.

In conclusion, the sulfate roasting of nickel sulfide ore has the advantages of high efficiency, short process, and strong adaptability to raw materials, but there are also some disadvantages such as high energy consumption, high cost, and waste gas.

Other Leaching There are other two routes in hydrometallurgical process for nickel extraction: (i) electrolysis refining/electrolysis (using soluble anode, crude nickel anode, and nickel sulfide anode) and (ii) selective leaching-electrolyte purification-electrodeposition. Among them, the second route has been developed rapidly and applied more widely. Electrolyte can also be used as one of the criteria for system selection, such as chlorination and sulfuric acid systems. Figure 5 shows a typical technological flow chart of chloridizing leaching-electrolyte purification-electrodeposition process. In this process, due to high chemical activity of chlorine, high solubility of generated chloride and strong complexing ability to impurities, nickel, cobalt, and copper in high-grade nickel matte can dissolve into the solution at normal temperature and pressure. Moreover, by adjusting the feeding rate of chlorine and raw materials, the redox potential in the leaching process can be controlled to realize continuous leaching. In addition, the system of ammonia, acid, and water can be selected as medium for leaching process.

Eksteen et al. [58] reported the outcomes of exploratory research relating to the atmospheric pressure and ambient temperature leaching of nickel and cobalt from a Western Australian low-grade, disseminated, nickel-cobalt sulfide ore, and the subsequent recovery by ion exchange (IX) using alkaline glycine solutions in mildly oxidizing environments. The study showed that even though glycine-based leach rates for nickel and cobalt are slow, no passivation was observed and about $83.5 \%$ nickel and $76.3 \%$ cobalt were extracted at room temperature using conventional bottle rolls over a $672 \mathrm{~h}$ period using a multistage extraction (i.e., leachate decant and reagent refresh with either new reagent or recycled barren raffinate). Amilton et al. [59] reported commercial chelating resins that can be applied in leach solutions with different compositions, and also possible innovations for uses of chelating resins to recover metals from mining process and mining tailings.
Fig. 5 The flowchart of chloridizing leaching process

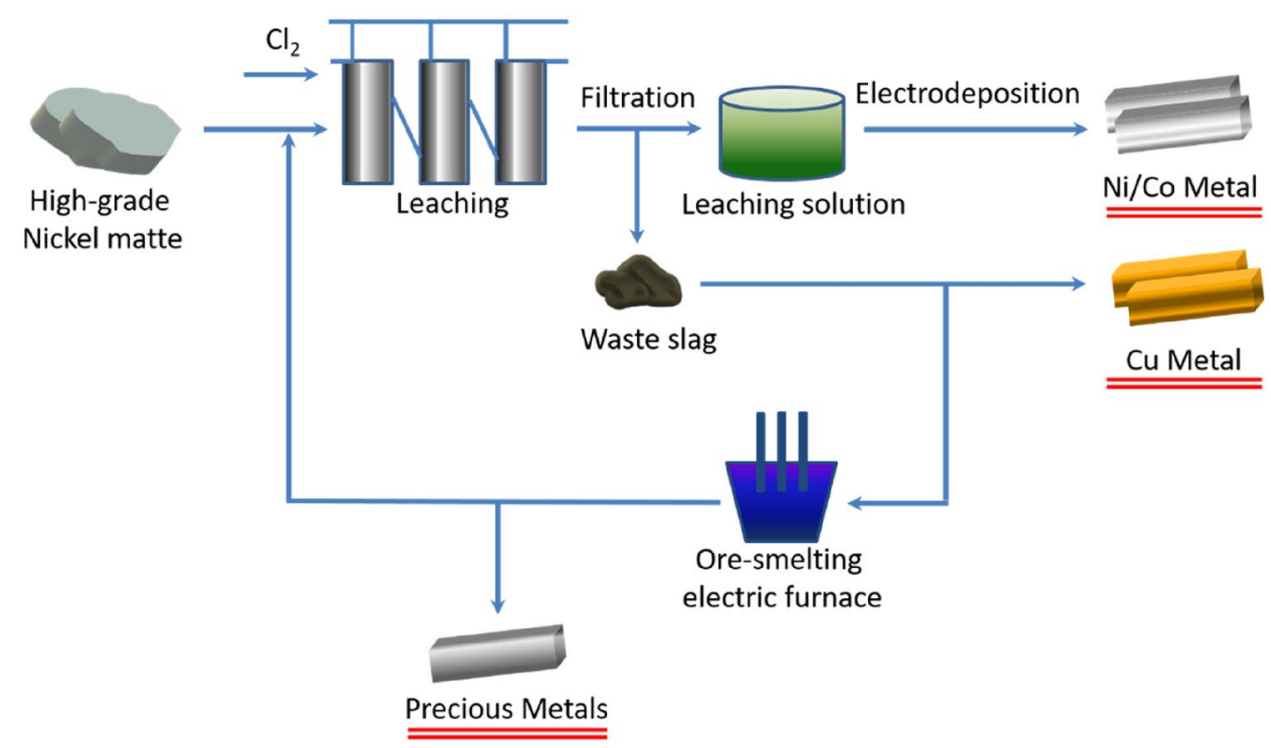




\section{Other Metallurgical Processes}

At present, the resources of high-grade and easy to treat nickel ore are diminishing, and more refractory low-grade nickel sulfide ore, oxidized ore, and mixed ore will eventually become the main source of nickel. Therefore, many methods with wider adaptability to raw materials have been developed, aiming at the efficient use of various existing nickel resources.

\section{Bioleaching Process}

Bioleaching is generally considered to be one of the effective technologies to directly extract metals and replace the traditional beneficiation and metallurgy process. Due to its characteristics of low investment, low cost, simple process flow, and environmental-friendly, bioleaching is suitable for treating low-grade and other refractory mineral resources and is considered to be the most promising process to replace the traditional leaching technology [60-62]. Its application in metallurgical industry has involved a variety of metals, among which the extraction of copper, uranium, and gold, etc. from ore has been industrialized. The bioleaching process of nickel and cobalt is still in the experimental stage. Bioleaching uses the oxidation or reduction of microorganisms to soak nickel and cobalt out of ore (or deposit) and make them enter the solution $[63,64]$. The valuable components can be separated from the original minerals in the form of soluble or precipitation, which is the direct effect of bioleaching process. Moreover, the process of obtaining valuable components through the reaction of biological metabolites and minerals is the indirect effect of the bioleaching process. The schematic diagram of biological leaching of sulfide ores is shown in Fig. 6.

According to the characteristics of nickel ore resources in China [65], the research on bioleaching mainly focuses on low-grade nickel sulfide ore. The current research results show that low-grade nickel ore resources (lean ore and tailings) had good bioleachability, and tailings were easier to leach than lean ore. But currently, the mechanism of the bioleaching process is undefined in addition to the slow bioleaching kinetics. Furthermore, the bio-oxidation process is an exothermic process, and each kind of bacteria can only adapt to a certain temperature range. Consequently, when the bio-oxidation process reaches a certain temperature, engineering problems such as overheating in the reactor have become the bottleneck of application.

\section{New Metallurgical Processes}

Wang et al. [66, 67] proposed a new process route for treatment of nickel complex minerals. Ionic liquids were used as solvents to selectively dissolve the reconstituted products, and then electrolysis/molten salt electrolysis is performed to obtain valuable metals and precious metals, respectively. The specific process flow is shown in Fig. 7.

In general, the content of iron in nickel sulfide ore is high, and it is rich in precious metals and other refractory metals. Ionic liquid can achieve selective extraction of copper, cobalt, and nickel $[68,69]$. The remaining slag mainly contains iron oxide and preliminarily enriched precious metals and refractory metals. Iron oxide contained in the slag can be electrolyzed in alkaline aqueous solution to prepare micro-nano-iron. However, it is still very difficult to realize the extraction, separation, and refining of precious/refractory metals through the current process, and new methods need to

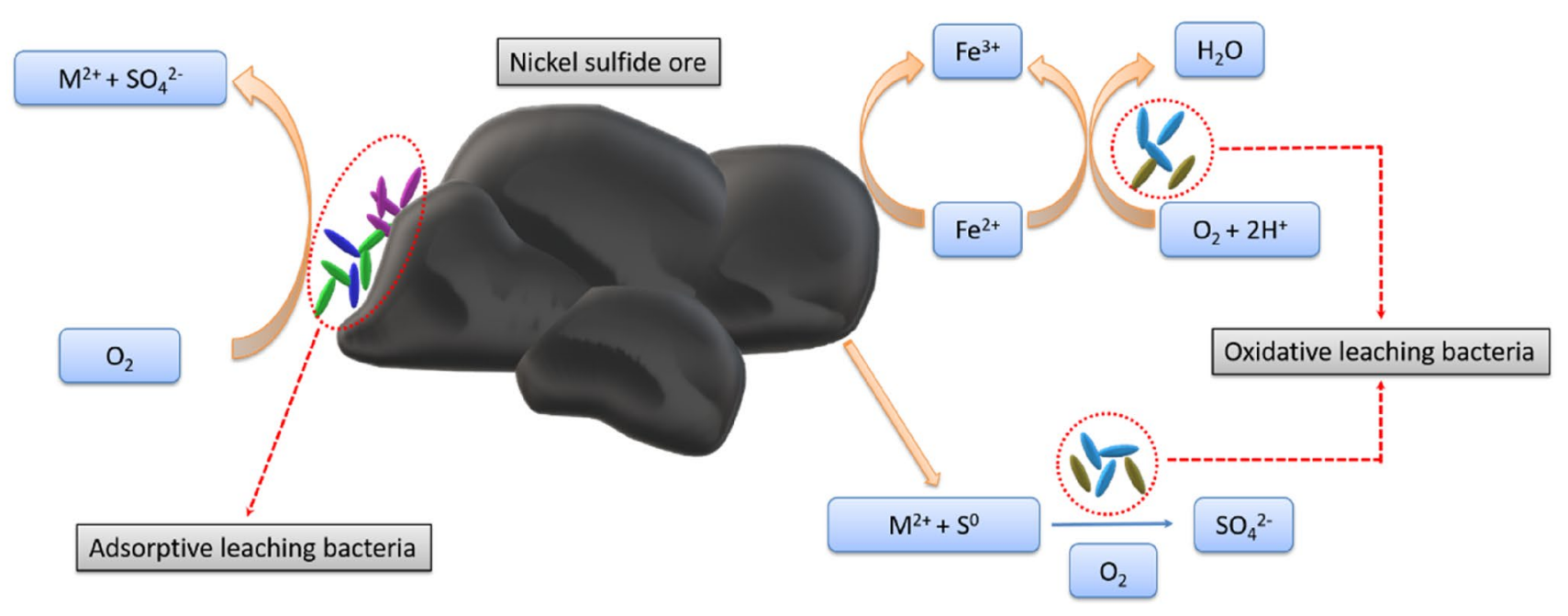

Fig. 6 Schematic diagram on biological leaching of sulfide ores 
Fig. 7 New route for comprehensive extraction of valuable metals/alloys from complex mineral phases

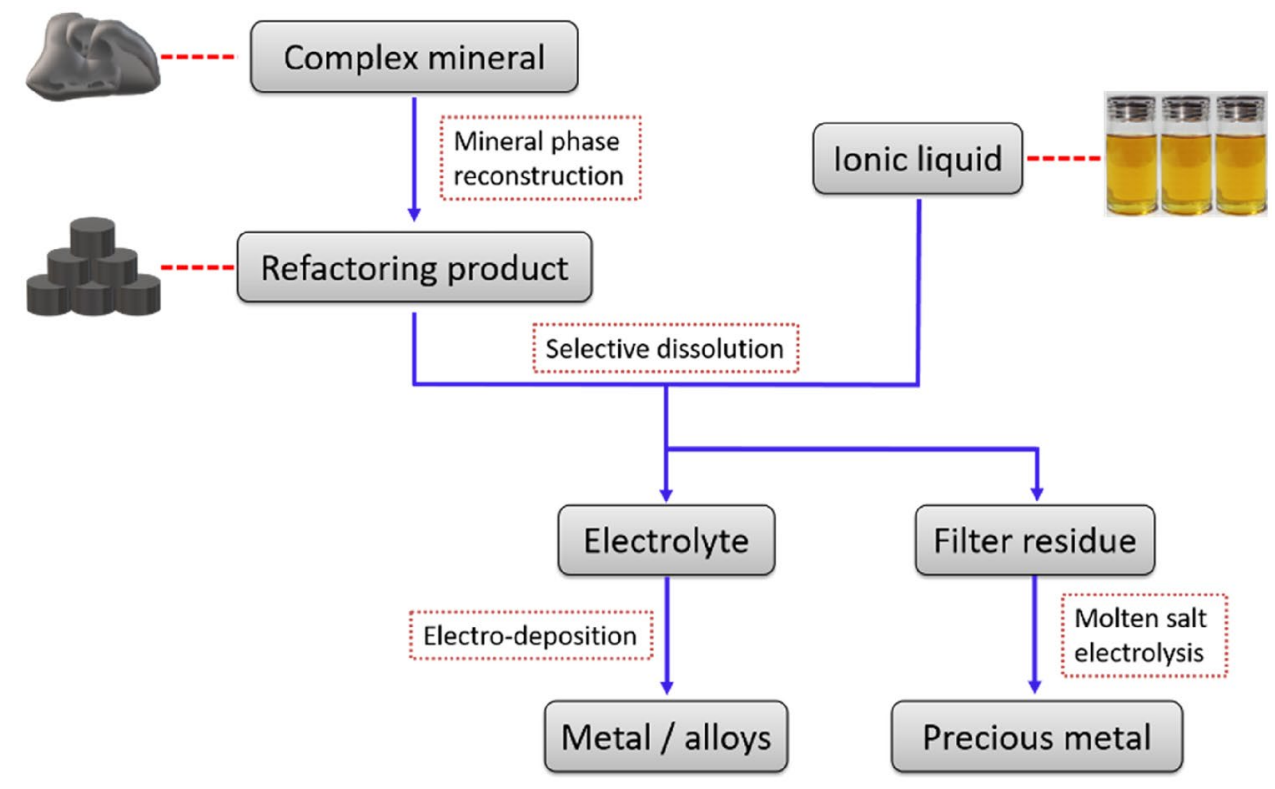

be further sought. In recent years, the development of molten salt electrolysis process continues to attract attention, the most typical of which are FFC Cambridge process [70, 71] and SOM method [72, 73]. Numerous studies [74-77] have shown that a variety of refractory metals such as tantalum, niobium, titanium, and some superalloys can be successfully prepared by molten salt electrolysis. It verifies the feasibility of treatment complex multicomponent composite ore using molten salt electrolysis. Simultaneously, a new idea can be provided that precious metals and refractory metals can be separated and produced from multicomponent slag by molten salt electrolysis.

\section{Conclusion and Prospect}

By comparing the main methods of extracting nickel from nickel sulfate ore listed above, it can be found that the typical pyrometallurgical process is simple, large in ore throughput, and easy to realize an industrial application. However, its disadvantages, such as high energy consumption, low added value of products, large loss of nickel, and the necessary waste-gas treatment, limit its development. Hydrometallurgy has become the mainstream technology for extracting nickel from nickel sulfide ores, with the advantages of high recovery rate and high product purity. Nevertheless, the high cost of wastewater treatment increases the capital investment of hydrometallurgical technology. Biometallurgy is regarded as the most promising clean technology in future because of its advantages of low energy consumption, low cost, and high metal recovery rate, but its shortcomings such as long leaching cycle, difficult to cultivate required bacteria, and susceptibility to pollution in the treatment process hindered its large-scale industrial application.

In recent years, with the depletion of global nickel sulfide concentrate resources and the rapid growth of nickel demand, the contradiction between nickel supply and demand has become increasingly prominent. Therefore, the efficient and clean extraction of nickel resources from nickel sulfide ore has important strategic significance for ensuring its supply safety and promoting the sustainable and healthy development of strategic emerging industries such as new energy vehicles. Based on the above analysis of nickel extraction technology from nickel sulfide ore and its advantages and disadvantages, the development trends and relevant suggestions for further strengthening the research on nickel extraction technology from nickel sulfide ore are put forward as follows:

(1) Atmospheric acid leaching will still be the preferred process for hydrometallurgical treatment of low-grade nickel sulfide ore. Although collaborative leaching can effectively shorten the process flow and reduce energy consumption and production costs, it is still in the laboratory research stage. Therefore, how to further expand the processing scale and increase the nickel recovery rate are the focus and difficult point that urgently needs to be broken. Moreover, the selective extraction of valuable metals cannot be achieved in the atmospheric leaching of nickel sulfide ore. It should be recommended to further strengthen the basis and application of selective extraction of nickel from nickel sulfide ore.

(2) Chlorination roasting process provides a cost-effective way to deal with low-grade nickel sulfide ore and tailings. With the development of new materials, the corro- 
sion problem of reaction equipment has been alleviated, but how to efficiently separate and purify the different metal components in the leachate is still the focus of attention.

(3) Nickel extraction technology from nickel sulfide ore based on "sulfated roasting-water leaching" can achieve high efficiency and clean extraction of nickel, but how to improve the utilization efficiency of sulfur in sulfated roasting is a bottleneck problem that needs to be solved urgently.

(4) Bioleaching has significant advantages in the treatment of low-grade nickel sulfide ore, but how to shorten the leaching period, improve the leaching efficiency, and develop strains that are easy to cultivate and adapt to different environments are still the bottleneck problems restricting its large-scale and extensive application.

On the other hand, with the decrease of high-grade and easily treatable nickel sulfide ore resources, the production of nickel increasingly depends on low-grade and refractory nickel oxide ore and nickel mixed ore. The development of related smelting technologies has promoted the energy saving and emission reduction of nickel industry to a large extent and has a broad development prospect. Furthermore, the waste brought from the industrial production process, such as spent Ni-based super alloys, batteries, solutions, and catalysts, can be used as the secondary resource of nickel, and it is also one of the important resources for the extraction of nickel in the nickel industry at present [10]. In the United States, even in the context of deadly COVID19 global pandemic, the secondary recovery and refining of nickel scrap produces about one hundred thousand tons of nickel in 2020, which overshoots the metal gross from ore processing and matte refining sources combined [9]. Nickel production from the secondary materials has a great potential because only $\sim 40 \%$ of the available nickel-bearing scrap is currently being recycled. Based on the demand for effective use of resources, strengthening the comprehensive utilization of secondary resources and developing material recycling technology can further promote the sustainable development and the energy saving and emission reduction of the metallurgical industry.

Acknowledgements This work was supported by the Science and Technology Research Project of Chongqing Education Commission, China [Grant Number KJQN202001408]; the Science and Technology Program of Chongqing, China [Grant Number cstc2021jcyj-msxmX0580]; and the Science and Technology Research Project of Chongqing Education Commission, China [Grant Number KJQN201901419].

\section{Declarations}

Conflict of interest The authors report that they have no conflict of interest.

\section{References}

1. Zhang Y, Xia G, Zhang J, Wang D, Dong P, Duan J (2020) Boosting high-voltage cyclic stability of nickel-rich layered cathodes in full-cell by metallurgy-inspired coating strategy. Appl Surf Sci 509:145380

2. Keim W (1990) Nickel: an element with wide application in industrial homogeneous catalysis. Angew Chem Int Ed Engl 29(3):235-244

3. Cui F, Wang G, Yu D, Gan X, Tian Q, Guo X (2020) Towards 'zero waste' extraction of nickel from scrap nickel-based superalloy using magnesium. J Clean Prod 262:121275

4. Gharabaghi M, Ejtemaei M, Irannajad M, Azadmehr AR (2012) Recycling of hazardous waste as a new resource for nickel extraction. Environ Technol 33(14):1569-1576

5. Xiao Z, Liu P, Song L, Cao Z, Du J, Zhou C, Jiang P (2021) The correlation between structure and thermal properties of nickelrich ternary cathode materials: a review. Ionics. https://doi.org/ 10.1007/s11581-021-04103-Z

6. Song L, Du J, Xiao Z, Jiang P, Cao Z, Zhu H (2020) Research progress on the surface of high-nickel nickel-cobalt-manganese ternary cathode materials: a mini review. Front Chem. https:// doi.org/10.3389/fchem.2020.00761

7. Díaz-González F, Sumper A, Gomis-Bellmunt O, VillafáfilaRobles R (2012) A review of energy storage technologies for wind power applications. Renew Sustain Energy Rev 16(4):2154-2171

8. Foley A, Olabi AG (2017) Renewable energy technology developments, trends and policy implications that can underpin the drive for global climate change. Renew Sustain Energy Rev 68:1112-1114

9. Geological Survey US (2021) Mineral commodity summaries 2020. U. S. Geological Survey, Washington, pp 112-113

10. Bolt J (1967) The winning of nickel—its geology. Mining and Extractive Metallurgy, Canada: Longman

11. Bocharov VL, Plaksenko AN (1989) Petrologic criteria for recognizing norite-diorite intrusions with regenerated nickel sulfide ores. Int Geol Rev 31(6):590-594

12. Crundwell F, Moats M, Ramachandran V, Robinson T, Davenport WG (2011) Extractive metallurgy of nickel, cobalt and platinum group metals. Elsevier, Amsterdam, pp 147-158

13. Meshram P, Pandey BD (2019) Advanced review on extraction of nickel from primary and secondary sources. Miner Process Extr Metall Rev 40(3):157-193

14. Barnes SJ, Osborne GA, Cook D, Barnes L, Maier WD, Godel B (2011) The Santa Rita nickel sulfide deposit in the Fazenda Mirabela intrusion, Bahia, Brazil: geology, sulfide geochemistry, and genesis. Econ Geol 106(7):1083-1110

15. Evans HT, Clark JR (1981) The crystal structure of bartonite, a potassium iron sulfide, and its relationship to pentlandite and djerfisherite. Am Miner 66(3-4):376-384

16. Vignes A (2013) Extractive metallurgy 2: metallurgical reaction processes. Wiley, New York, pp 273-295

17. Melcher F, Onuk P (2019) Potential of critical high-technology metals in eastern alpine base metal sulfide ores. BHM Berg-und Hüttenmännische Monatshefte 164(2):71-76

18. Crundwell FK, Moats MS, Ramachandran V, Robinson TG, Davenport WG (2011) Smelting of nickel sulfide concentrates by roasting and electric furnace smelting. Extractive Metallurgy of Nickel, Cobalt and Platinum Group Metals. Elsevier, Amsterdam

19. Sukhomlinov D, Virtanen O, Latostenmaa P, Jokilaakso A, Taskinen $\mathrm{P}$ (2019) Impact of $\mathrm{MgO}$ and $\mathrm{K}_{2} \mathrm{O}$ on slag-nickel matte equilibria. J Phase Equilib Diffus 40(6):768-778 
20. Diaz CM, Landolt CA, Vahed A, Warner AEM, Taylor JC (1988) A review of nickel pyrometallurgical operations. JOM 40(9):28-33

21. Warner AEM, Diaz CM, Dalvi AD, Mackey PJ, Tarasov AV, Jones RT (2007) JOM world nonferrous smelter survey Part IV: nickel: sulfide. JOM 59(4):58-72

22. Queneau PE (1970) The recovery of nickel from its ores. JOM 22(10):44-48

23. Wang F, Marcuson S, Khajavi L T, Barati M (2021) One-step extraction of nickel from nickel sulfide concentrates by iron addition. In Ni-Co 2021: the 5th international symposium on nickel and cobalt. Doi: https://doi.org/10.1007/978-3-030-65647-8_20

24. Wang F, Liu F, Elliott R, Rezaei S, Khajavi LT, Barati M (2020) Solid state extraction of nickel from nickel sulfide concentrates. J Alloys Compd 822:153582

25. McDonald RG, Li J, Austin PJ (2020) High temperature pressure oxidation of a low-grade nickel sulfide concentrate with control of the residue composition. Minerals. https://doi.org/10.3390/min10 030249

26. Tong L, Dreisinger D (2009) Interfacial properties of liquid sulfur in the pressure leaching of nickel concentrate. Miner Eng 22(5):456-461

27. Huang K, Li QW, Chen J (2007) Recovery of copper, nickel and cobalt from acidic pressure leaching solutions of low-grade sulfide flotation concentrates. Miner Eng 20(7):722-728

28. Baba AA, Ghosh MK, Pradhan SR, Rao DS, Baral A, Adekola FA (2014) Characterization and kinetic study on ammonia leaching of complex copper ore. Trans Nonferrous Met Soc China 24(5):1587-1595

29. Radmehr V, Koleini S M J, Khalesi M R, Tavakoli M R (2012) Ammonia leaching in the copper industry: a review. In: XXVI international mineral processing congress (IMPC) proceedings, pp 02512-02523

30. Meng X, Han KN (1996) The principles and applications of ammonia leaching of metals-a review. Miner Process Extr Metall Rev 16(1):23-61

31. Chen JY (2005) Handbook of hydrometallurgy, hydrometallurgy of nickel and cobalt. Metallurgical Industry Press, Beijing

32. Peters E (1976) Direct leaching of sulfides: chemistry and applications. Metall Trans B 7(4):505-517

33. Karimov K, Shoppert A, Rogozhnikov D, Kuzas E, Zakhar'yan S, Naboichenko S (2020) Effect of preliminary alkali desilication on ammonia pressure leaching of low-grade copper-silver concentrate. Metals 10(6):812

34. Kerfoot D G E, Cordingley P D (1997) The acid pressure leach process for nickel and cobalt laterite. Part II: review of operations at Fort Saskatchewan. In: Proceedings of the nickel-cobalt 97 international symposium, WC Cooper and I. Mihaylov, Sudbury, Canada, pp 355-370

35. Ma“ kinen T, Taskinen P (2008) State of the art in nickel smelting: direct Outokumpu nickel technology. Miner Process Extr Metall 117(2):86-94

36. Berezowsky RMGS, Collins MJ, Kerfoot DGE, Torres N (1991) The commercial status of pressure leaching technology. JOM 43(2):9-15

37. Amer AM (1995) Investigation of the direct hydrometallurgical processing of mechanically activated complex sulphide ore, Akarem area, Egypt. Hydrometallurgy 38(3):225-234

38. Muszer A, Wódka J, Chmielewski T, Matuska S (2013) Covellinisation of copper sulphide minerals under pressure leaching conditions. Hydrometallurgy 137:1-7

39. Provis JL, Van Deventer JSJ, Rademan JAM, Lorenzen L (2003) A kinetic model for the acid-oxygen pressure leaching of $\mathrm{Ni}-\mathrm{Cu}$ matte. Hydrometallurgy 70(1-3):83-99
40. Xiao W, Liu X, Zhao Z (2020) Kinetics of nickel leaching from low-nickel matte in sulfuric acid solution under atmospheric pressure. Hydrometallurgy 194:105353

41. Xiao W, Sun F, Liu X, Zhao Z (2021) Sulfuric acid leaching for low nickel matte under atmospheric pressure. In: Ni-Co 2021: the 5th international symposium on nickel and cobalt, pp 219-226

42. Xie YT, Xu YB, Yan L, Yang RD (2005) Recovery of nickel, copper and cobalt from low-grade Ni-Cu sulfide tailings. Hydrometallurgy 80(1-2):54-58

43. Dyson NF, Scott TR (1976) Acid leaching of nickel sulphide concentrates. Hydrometallurgy 1(4):361-372

44. Jha MC, Carlberg JR, Meyer GA (1983) Hydrochloric acid leaching of nickel sulfide precipitates. Hydrometallurgy 9(3):349-369

45. Xing Z, Cheng G, Yang H, Xue X, Jiang P (2020) Mechanism and application of the ore with chlorination treatment: a review. Miner Eng 154:106404

46. Mukherjee TK, Gupta CK (1983) Base metal resource processing by chlorination. Miner Process Extr Metall Rev 1(1-2):111-153

47. Kershner KK, Hoertel FW (1961) Recovering cobalt and nickel from complex sulfide ores of southeastern missouri, US Department of the Interior, Bureau of Mines

48. Mukherjee TK, Menon PR, Shukla PP, Gupta CK (1985) Chloridizing roasting process for a complex sulfide concentrate. JOM 37(6):29-33

49. Imideev VA, Aleksandrov PV, Medvedev AS, Bazhenova OV, Khanapieva AR (2014) Nickel sulfide concentrate processing using low-temperature roasting with sodium chloride. Metallurgist 58(5):353-359

50. Li G, Zou X, Cheng H, Geng S, Xiong X, Xu Q, Zhou Z, Lu X (2020) A novel ammonium chloride roasting approach for the high-efficiency Co-sulfation of nickel, cobalt, and copper in polymetallic sulfide minerals. Metall Mater Trans B 51(6):2769-2784

51. Cui F, Mu W, Zhai Y, Guo X (2020) The selective chlorination of nickel and copper from low-grade nickel-copper sulfide-oxide ore: mechanism and kinetics. Sep Purif Technol 239:116577

52. Xiao TF, Mu WN, Shi S, Xin H, Xu X, Cheng H, Luo S, Zhai YC (2021) Simultaneous extraction of nickel, copper, and cobalt from low-grade nickel matte by oxidative sulfation roasting-water leaching process. Miner Eng 174:107254

53. Thornhill P G (1957) U.S. Patent No. 2,813,015. Washington, DC: U.S. Patent and Trademark Office. 1957-11-12

54. Yu D, Utigard TA, Barati M (2014) Fluidized bed selective oxidation-sulfation roasting of nickel sulfide concentrate: Part II. Sulfation roasting. Metall Mater Trans B 45(2):662-674

55. Mu W, Cui F, Huang Z, Zhai Y, Xu Q, Luo S (2018) Synchronous extraction of nickel and copper from a mixed oxide-sulfide nickel ore in a low-temperature roasting system. J Clean Prod 177:371-377

56. Liu XW, Feng YL, Li HR, Yang ZC, Cai ZL (2012) Recovery of valuable metals from a low-grade nickel ore using an ammonium sulfate roasting-leaching process. Int J Miner Metall Mater 19(5):377-383

57. Cui F, Mu W, Wang S, Xin H, Xu Q, Zhai Y, Luo S (2018) Sodium sulfate activation mechanism on co-sulfating roasting to nickelcopper sulfide concentrate in metal extractions, microtopography and kinetics. Miner Eng 123:104-116

58. Eksteen JJ, Oraby EA, Nguyen V (2020) Leaching and ion exchange based recovery of nickel and cobalt from a low grade, serpentine-rich sulfide ore using an alkaline glycine lixiviant system. Miner Eng 145:106073

59. Junior ABB, Dreisinger DB, Espinosa DC (2019) A review of nickel, copper, and cobalt recovery by chelating ion exchange resins from mining processes and mining tailings. Min Metall Explor 36(1):199-213 
60. Watling HR (2008) The bioleaching of nickel-copper sulfides. Hydrometallurgy 91(1-4):70-88

61. Watling HR, Elliot AD, Maley M, Van Bronswijk W, Hunter C (2009) Leaching of a low-grade, copper-nickel sulfide ore. 1. Key parameters impacting on $\mathrm{Cu}$ recovery during column bioleaching. Hydrometallurgy 97(3-4):204-212

62. Cruz FL, Oliveira VA, Guimarães D, Souza AD, Leão VA (2010) High-temperature bioleaching of nickel sulfides: thermodynamic and kinetic implications. Hydrometallurgy 105(1-2):103-109

63. Johnson DB (2014) Biomining-biotechnologies for extracting and recovering metals from ores and waste materials. Curr Opin Biotechnol 30:24-31

64. Rawlings DE (2004) Microbially-assisted dissolution of minerals and its use in the mining industry. Pure Appl Chem 76(4):847-859

65. Zhong LT, Duan JR (1988) Types and metallogenic models of nickel sulfide deposits of China. Acta Geol Sin 1(2):193-206

66. Wang D, Lu C, Zou X, Zheng K, Zhou Z, Lu X (2018) Electrolysis of converter matte in molten $\mathrm{CaCl}_{2}-\mathrm{NaCl}$. J Mater Sci Chem Eng 6(2):1-11

67. Wang T, Gao H, Jin X, Chen H, Peng J, Chen GZ (2011) Electrolysis of solid metal sulfide to metal and sulfur in molten $\mathrm{NaCl}-$ KCl. Electrochem Commun 13(12):1492-1495

68. Tran TT, Azra N, Iqbal M, Lee MS (2020) Synthesis of succinimide based ionic liquids and comparison of extraction behavior of Co (II) and Ni (II) with bi-functional ionic liquids synthesized by Aliquat336 and organophosphorus acids. Sep Purif Technol 238:116496

69. Wasserscheid P, Hilgers C, Keim W (2004) Ionic liquids-weaklycoordinating solvents for the biphasic ethylene oligomerization to $\alpha$-olefins using cationic Ni-complexes. J Mol Catal A: Chem 214(1):83-90

\section{Authors and Affiliations}

\section{Kun Zhao ${ }^{1} \cdot$ Feng $\mathrm{Gao}^{2} \cdot$ Qunying Yang ${ }^{1}$}

Kun Zhao

zkngwt@126.com

1 College of Material Science and Engineering, Yangtze Normal University, Chongqing, China
70. Chen GZ, Fray DJ, Farthing TW (2000) Direct electrochemical reduction of titanium dioxide to titanium in molten calcium chloride. Nature 407:361-364

71. Fray DJ, Chen GZ (2004) Reduction of titanium and other metal oxides using electrodeoxidation. Mater Sci Technol 20(3):295-300

72. Pal UB, Woolley DE, Kenney GB (2001) Emerging SOM technology for the green synthesis of metals from oxides. JOM 53(10):32-35

73. Zou X, Lu X, Li C, Zhou Z (2010) A direct electrochemical route from oxides to $\mathrm{Ti}-\mathrm{Si}$ intermetallics. Electrochim Acta 55(18):5173-5179

74. Wu T, Jin X, Xiao W, Hu X, Wang D, Chen GZ (2007) Thin pellets: fast electrochemical preparation of capacitor tantalum powders. Chem Mater 19(2):153-160

75. Ueda I, Baba M, Kikuchi T, Suzuki RO (2013) Formation of niobium powder by electrolysis in molten salt. Electrochim Acta 100:269-274

76. Zhao K, Wang Y, Peng J, Di Y, Liu K, Feng N (2016) Formation of $\mathrm{Ti}$ or $\mathrm{TiC}$ nanopowder from $\mathrm{TiO}_{2}$ and carbon powders by electrolysis in molten $\mathrm{NaCl}-\mathrm{KCl}$. RSC Adv 6(11):8644-8650

77. Wu C, Tan M, Ye G, Fray DJ, Jin X (2019) High-efficiency preparation of titanium through electrolysis of carbo-sulfurized titanium dioxide. ACS Sustain Chem Eng 7(9):8340-8346

Publisher's Note Springer Nature remains neutral with regard to jurisdictional claims in published maps and institutional affiliations.

2 School of Chemistry and Chemistry Engineering, Yangtze Normal University, Chongqing, China 